\title{
Promoting healthy food education for elementary school children at post Merapi eruption area of Cangkringan district, Yogyakarta, Indonesia: A quasi experimental study using 'learning with fun' approach
}

\author{
Agnes Erida Wijayanti ${ }^{* 1,2}$, Lely Lusmilasari ${ }^{2}$, Mora Claramita ${ }^{3}$ \\ ${ }^{1}$ Department of Nursing, Wira Husada School of Health Sciences, Yogyakarta, Indonesia \\ ${ }^{2}$ Department of Nursing, Faculty of Medicine, Gadjah Mada University, Yogyakarta, Indonesia \\ ${ }^{3}$ Department of Medical Education and Department of Family and Community Medicine, Faculty of Medicine, Gadjah Mada \\ University, Yogyakarta, Indonesia
}

Received: August 14, 2016

DOI: $10.5430 /$ jnep.v7n3p128
Accepted: October 10, $2016 \quad$ Online Published: November 15, 2016

URL: http://dx.doi.org/10.5430/jnep.v7n3p128

\begin{abstract}
Background: Knowledge and attitudes towards healthy food intake influence the growth and development of school-aged children. Cangkringan district of Yogyakarta, Indonesia was the worst area affected by the Mount Merapi eruption in 2010 and has a long-term consequence of less healthy food available for school-age children. This study aimed to determine the effect of health education to increase knowledge and attitudes towards healthy food intake for elementary school children at Cangkringan. Methods: Respondents of this study were 338 elementary school children (134 boys and 204 girls, ages between 8-10 years old) at Cangkringan. There were 20 elementary schools involved and participants were divided into 36 groups to make small groups of 6 to 8 students. Interventions of this study involved serial health education via 'learning with fun' approach using a student-centered learning method. The authors developed all tools and instruments based on the guidelines from The Food and Agriculture Organization (FAO). We analyzed the knowledge and attitude of the subjects after administering a pre and posttest using paired t-test and Wilcoxon range test.

Results: The results showed significant increase of knowledge and attitudes towards healthy food intake $(p<.001$ for both knowledge and attitude) of all subjects in this study.

Conclusions: Health education using 'learning with fun' method may increase knowledge and attitudes of elementary school children. Furthermore, a series of cooking-classes as a student-centered learning approach, which emphasized contextual, collaborative and constructive methods of learning served well to increase motivation and satisfaction of the students to learn about healthy food.
\end{abstract}

Key Words: Health education, Learning with fun approach, Student-centered learning, nutrition, Cangkringan Indonesia

\section{INTRODUCTION}

Diseases and malnutrition will affect the growth and development of school-aged children. This condition could potentially interfere with the development during the early learning periods. ${ }^{[1]}$ Knowledge or the cognitive domain is an important domain to stimulate behavior changing (overt be-

\footnotetext{
*Correspondence: Agnes Erida Wijayanti; Email: eridaagnes@ gmail.com; Address: Department of Nursing, Wira Husada School of Health Sciences, Yogyakarta, Indonesia.
} 
havior). Social cognitive theory acknowledges the influential role of evolutionary factors of learning in human adaptation and change, which accommodates a more active contextual learning. ${ }^{[2]}$ One of the implementations of that theory is an active learning method that provides engaging enrichment experiences for reflection and experiential learning.

A study by Leong showed that Health education using active learning methods with a booklet, flipchart and cooking competition significantly increased the knowledge and attitudes on healthy food intake for school-aged children. ${ }^{[3]}$ Active learning is an appropriate and important way for children to develop skills and knowledge and positive attitudes toward learning. In this approach, children are challenged to learn more actively by encountering real life experiences and learning activities to use the power of imagination in every situation. It takes full advantage of the opportunity to learn through spontaneous activity while playing, and doing some fun cruising activity. They learn to conduct a situation analysis, looking at and reflecting on life events, as well as focusing on active learning. ${ }^{[4]}$

A study of an elementary school in Taiwan, reported that 50\% of 1,218 respondents had low knowledge about the importance of healthy nutrition. Better nutrition can lead to better knowledge and attitudes as foundations of critical thinking skills. It is important to have a healthy diet for school children both at home as well as at school. However, most school children might not consume sufficient nutritious food in their daily life. ${ }^{[5]}$ Another study in Brazil in 2004 also reported similar low knowledge among $90 \%$ of 573 elementary school children who had a low knowledge of healthy nutrition. ${ }^{[6]}$

Nevertheless, different results were found by a study in New Zealand where approximately $80 \%$ of the students reported that they can cook a meal from basic ingredients either fairly or very easily. The ability to prepare meals was consistent with the better knowledge and health status among schoolage children in New Zealand. This study of Utter et al. from New Zealand explored secondary school children who are older students than from the previous studies from Taiwan and Brazil. We aimed to replicate Utter's design into our study, but applied the methods to elementary school children. Learning to cook and having the opportunity to cook may provide unique means for children to develop life skills and contribute positively to their families. Future research examining the relationships between cooking and health may include measures beyond nutrition, such as social relationships and emotional wellbeing. ${ }^{[7]}$ Contributions of active teaching-learning methodologies had raised awareness towards healthy habits: particularly, feeding and physical exercising. The use of active methodologies may unfold new

Published by Sciedu Press possibilities towards healthy habits and practices. ${ }^{[8]}$

In Indonesia, a national survey based on the Basic Health Research of Indonesia, showed that there is a less optimum body growth or 'thinness' of elementary school-aged children (below the red line or below normal) ranged from $2 \%$ to $12 \%$ per province among 33 provinces. Nationally, there were $4 \%$ 'very thin' and $7 \%$ 'thin'. Whereas, the prevalence of the school-aged children who are so called 'very thin' was lowest in Bali with 2.3\%, Special Region of Yogyakarta 2.5\% and the highest was in East Nusa Tenggara with 7.8\%.

Besides the issue of thinness, there is a problem of obesity among school age children in Indonesia. School children aged 5-12 years have $18.8 \%$ and $10.8 \%$ who are 'overweight' and 'very overweight' respectively and $8.8 \%$ were considered 'obese'. The prevalence of obesity was lowest in East Nusa Tenggara with $8.7 \%$ and the highest was in Jakarta that was $30.1 \%$. The prevalence of obesity in Yogyakarta province where this study was done was $9.2 \%{ }^{[9]}$

Health professionals, especially nurses, have very important roles of promoting healthy lifestyles including healthy food intake and adequate nutrition supply for school-age children especially for nurses who have daily contact with the public. ${ }^{[10]}$ This study aimed to determine the effect of health education to increase knowledge and attitudes towards healthy food intake for elementary school children at Cangkringan district, Yogyakarta through using a 'learning with fun approach' with a series of interesting cooking classes. Focusing more on a student-centered learning approach served well to increase knowledge and attitudes towards healthy food intake for elementary school children in the Cangkringan district, Yogyakarta.

\section{METHOD}

\subsection{Design and sample}

This study was an experimental research with a one-group pretest-posttest design. The study was conducted at 20 elementary schools in the Cangkringan district Sleman Yogyakarta Indonesia. The authors were interested about the Cangkringan district of Yogyakarta for this study setting because it has the characteristics of more underdeveloped areas, and was severely effected by the Mount Merapi explosion in 2010; while having 20 elementary schools which are now full of school-aged children who need more attention for their learning development.

\subsection{Context of this study}

Cangkringan is an area that was badly affected by the eruption of Mount Merapi on the 26th of October, 2010 with two of five villages being hit by hot ash clouds. The im- 
pact of this disaster resulted in numerous occurrences of emergencies in all fields including emergency situations and problems in health and nutrition. Health problems often arise at post-disaster sites when disaster victims become used to consuming 'ready to eat food' (food to make sure the victims get the intake of energy, protein and fat to maintain life), for examples: biscuits, instant noodles, and instant cereal. ${ }^{[11]}$ However, six years later the children in the Cangkringan district are still eating instant noodles in the consumption of their everyday meals, instead of their parents trying to prepare a more nutritious and proper meal for them. This phenomenon may be happening because of a lack of education and be due to less adequate health promotion about the importance of healthy food intake, especially in nationwide programs for the members of families with school-aged children.

The context of this study is that there are no formal cafeterias assigned to supply regular meals for the school aged children in the Cangkringan district, Yogyakarta. Elementary schools in the Cangkringan district start at 7 o'clock a.m. and are finished at 12 o'clock noon with two 15 minutes break in between classes for recess time. This kind of school-period from seven to twelve is common all around Indonesia. Students rarely bring their meal from home, rarely take regular breakfast and usually they buy less expensive food from small food vendors in front of the elementary schools, where the nutrition, hygiene and sanitation could not be guaranteed.

\subsection{Subject of the study}

Respondents in this research included 134 boys and 204 girls between 8-10 years old who live in the Cangkringan district. Total number of respondents was 338 school aged children. Determination of the number of respondents used cluster sampling by considering the following inclusion and exclusion criteria: willing to be the subjects of this study, following the statements filled in the informed consent form and would like to follow through with research process procedures. Exclusion was serious illness before or while joining this study. Teachers helped to select respondents and also asked parents for permission and willingness to participate in this research. Given informed consent of subjects in this study, our proposal was approved by the ethics committee of Gadjah Mada University Yogyakarta, Indonesia. (Approval Letter Ref: KE/FK/915/EC/2015 dated 23 July 2015) (see Figure 1).

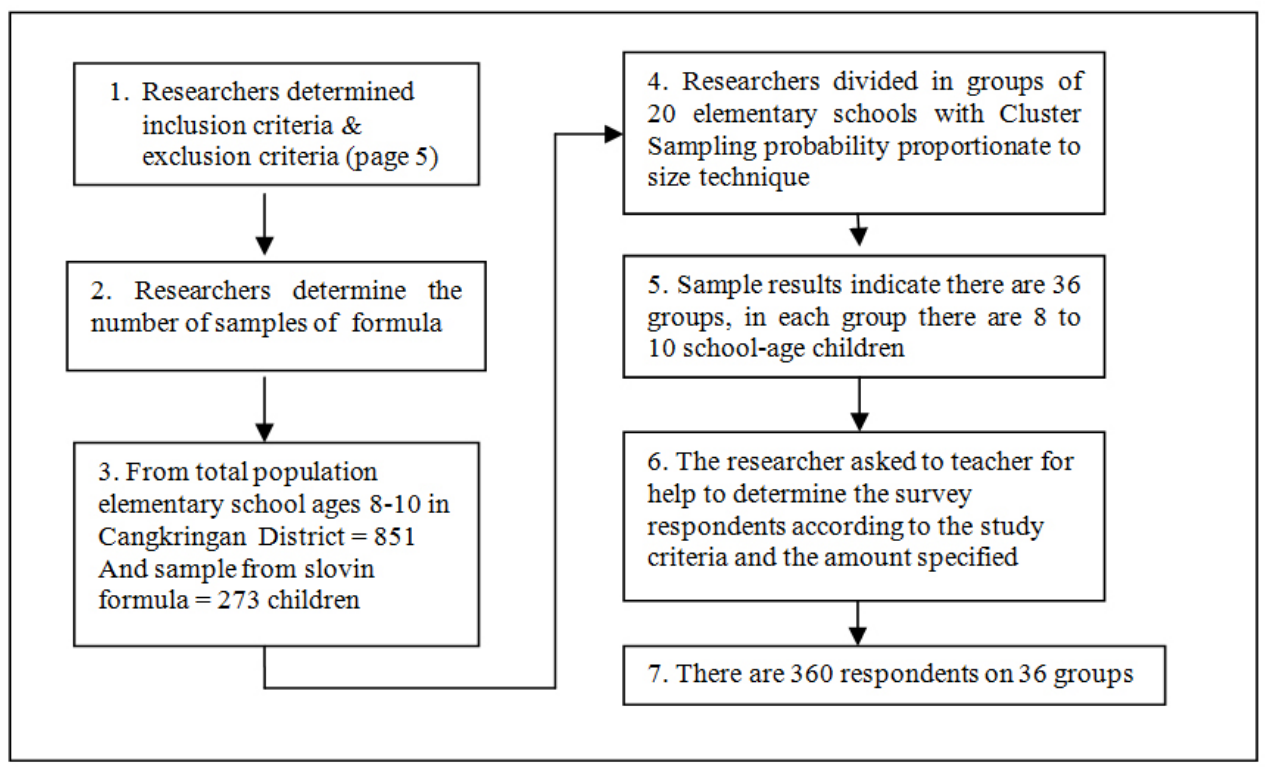

Figure 1. Procedures of sample selection

Measurement of knowledge and attitudes was conducted using questionnaires consisting of a multiple-choice test and matching pictures (see Figure 2). The questionnaire about knowledge and attitudes developed by the researchers adopted the guidelines for assessing nutrition related knowledge, attitudes and practices of Food and Agriculture Organization (FAO), in Rome, 2014. The questionnaire had previously been used in related research by Zalilah et al. (2008) in Malaysia with 335 research subjects.

\subsection{Instrument}

Collection of data using pretest and posttest instruments was as follows: Instrument number 1 was a set of questionnaires A consisting of personal data of respondent (gender, age, 
parents' education, parent's job) (see Table 1). Instrument number 2 was a set of questionnaires B consisting of questions of knowledge on healthy food; Children's understanding about healthy food including 10 messages of balanced nutrition (thankful and joyful, eat plenty fruits and vegetable; accustomed to consume high protein side dishes, consuming kinds of staple food, limitation of sweet food, fatty and other ingredients, accustomed to eating breakfast, drinking enough water; reading food packaging labels; importance of hand washing, and physical activity. The questions numbered 20 items consisting of matching pictures and expla- nations; and multiple-choice questions using 'Yes' (scored 1) or 'No' (scored zero). Instrument number 3 was a set of questionnaires $\mathrm{C}$ consisting of questions on attitudes about healthy food; positive responses were shown by the children in choosing, preparing and consuming healthy food in daily life. These questionnaires used a 4 point-Likert scale: For positive sentences, 1 meant very disagree; 2 meant disagree; 3 meant agree; and 4 meant very agree. For negative questions, 1 meant very agree; 2 meant agree; 3 meant disagree; and 4 meant very disagree. ${ }^{[12]}$

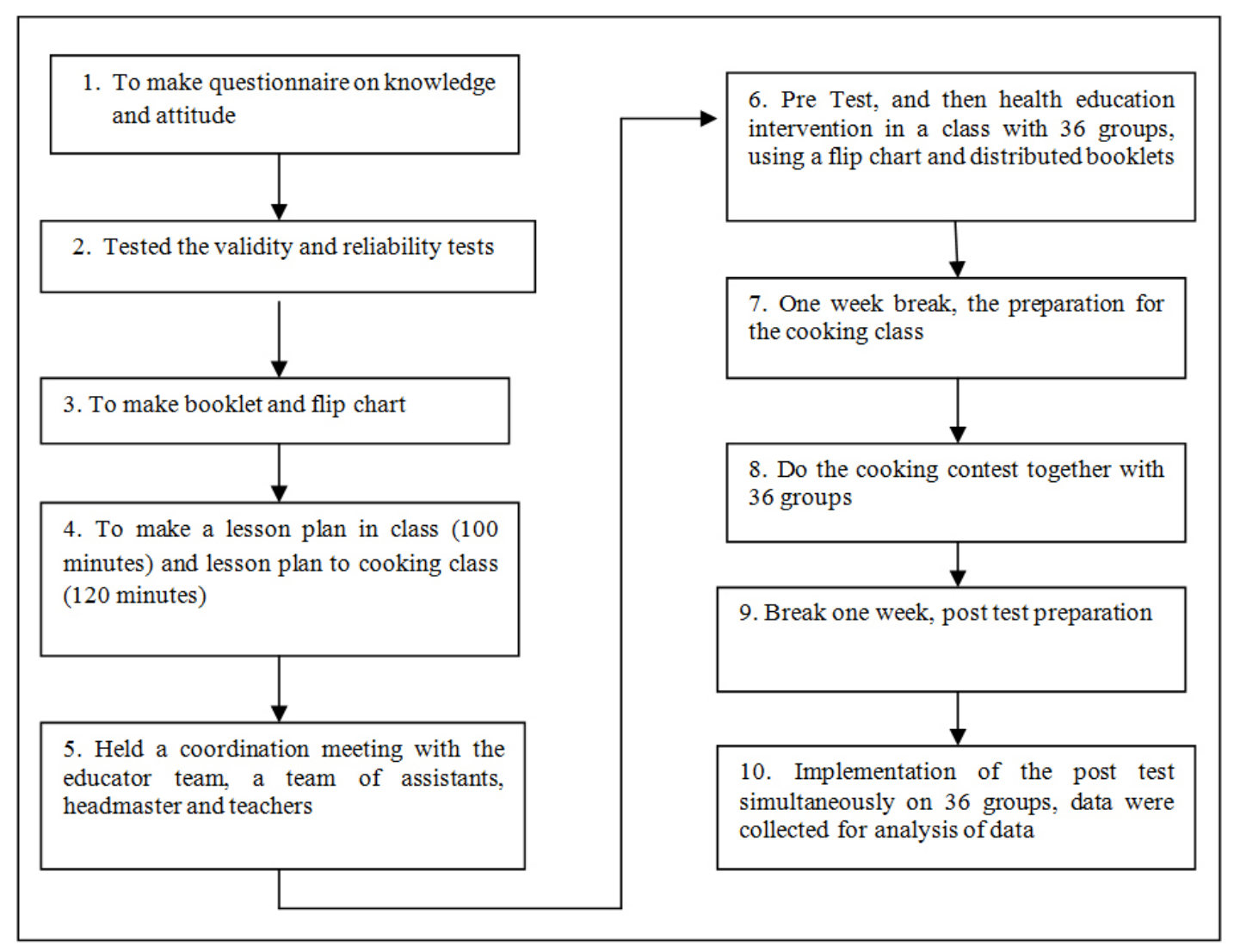

Figure 2. Research procedure

Prior to distribution of questionnaires, the authors tested the validity and reliability of the questionnaires on 30 samples of school-age children with similar characteristics in elementary schools from different districts. Of the 30 questions of knowledge there were 9 items rejected, whereas for the 20 attitude questions 7 items were rejected. The rejected items were then modified into more meaningful sentences. Reliability test results in the area of knowledge showed Cronbach's alpha value of 0.861 and in the area of attitude showed Cronbach's alpha value of 0.756 . The questionnaires had previously been tested using pictures and interesting writing with Indonesian language, establishing the reliability and

Published by Sciedu Press face validity of the instrument. ${ }^{[13]}$

All questionnaires were tested for the content validity by experts at the Department of Nursing, Faculty of Medicine, the Department of Medical Education, and the Department of Family and Community Medicine, Faculty of Medicine, Gadjah Mada University.

\subsection{Ethical approval}

This study was approved by Medical and Health Research Ethics Committee (MHREC), of the Faculty of Medicine Gadjah Mada University (Approval Letter Ref: KE/FK/915/EC/2015 dated 23 July 2015). 
Table 1. Characteristics of research samples $(n=338)$

\begin{tabular}{|c|c|c|c|}
\hline Variables & & Frequency & $\%$ \\
\hline \multirow[t]{2}{*}{ Gender } & Male & 134 & 39.6 \\
\hline & Female & 204 & 60.4 \\
\hline \multirow[t]{3}{*}{ Age } & 8 years & 50 & 14.8 \\
\hline & 9 years & 197 & 58.3 \\
\hline & 10 years & 91 & 26.9 \\
\hline \multirow[t]{3}{*}{ Father Education } & Elementary & 143 & 42.3 \\
\hline & Secondary & 153 & 45.3 \\
\hline & High & 42 & 12.4 \\
\hline \multirow[t]{3}{*}{ Mother Education } & Elementary & 151 & 44.7 \\
\hline & Secondary & 145 & 42.9 \\
\hline & High & 42 & 12.4 \\
\hline \multirow[t]{3}{*}{ Father occupation } & Work at home & 127 & 37.6 \\
\hline & Working outside home & 209 & 61.8 \\
\hline & Does not work & 2 & 0.6 \\
\hline \multirow[t]{3}{*}{ Mother occupation } & Work at home & 96 & 28.4 \\
\hline & Working outside home & 176 & 52.1 \\
\hline & Does not work & 66 & 19.5 \\
\hline
\end{tabular}

\subsection{Procedures}

As shown in Figure 2 it can be explained that the research process followed a step by step method starting from, to make the questionnaire about knowledge and attitudes, then to do the validity and reliability tests, next to make the booklet and flip chart, then to make a lesson plan for the health class (100 minutes) and lesson plan for the cooking class
(120 minutes) (see Figure 3). Participants were assured that all information would be confidential and their participation in the study was voluntary without any cost and they have the right to refuse to participate in the study at any point in the study. Also, a written approval was obtained from the Ethics Committee of Gadjah Mada University Yogyakarta, Indonesia.

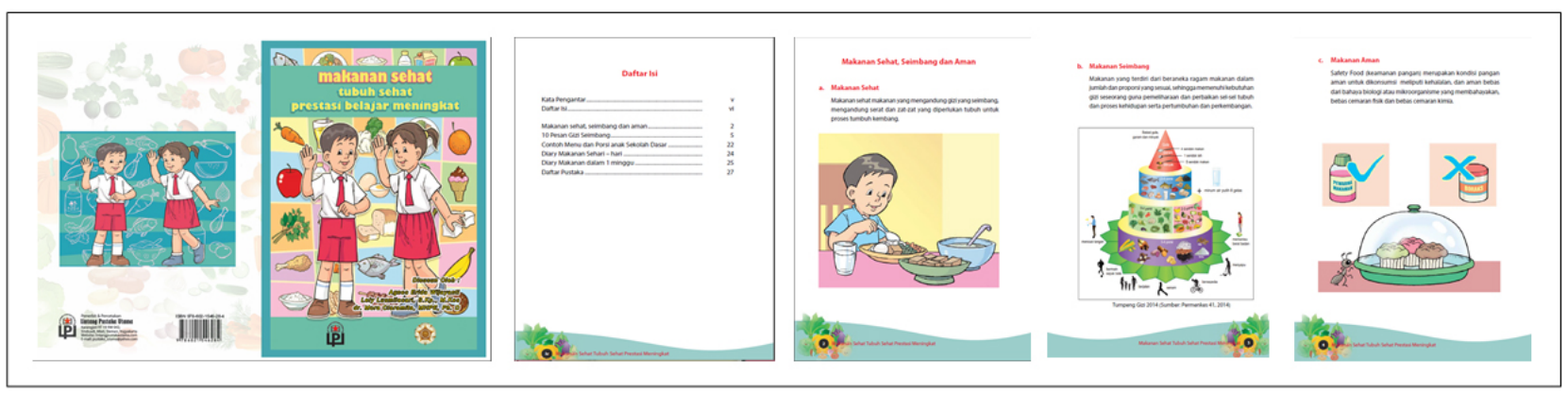

Figure 3. Representation of educational booklet

Researchers conducted a coordination meeting with the educator team, research assistants, and also the headmaster and teachers. To have the same perception of conducting health promotion on healthy food to the school children in this study, the educator team was required to conduct a micro teaching, using the research instruments and then were given feedback by peers, prior to the implementation of this study. After that, the team of researchers conducted a pre-test, and then did the health education intervention in a class with 36 groups, using a flip chart and distributed booklets. These activities were followed by a cooking contest together with the 36 groups; after a one-week break, involving the preparation time for the cooking class. A post-test were obtained one week after the cooking contest from the 36 groups, and data were collected for analysis.

In summary of procedures, this study was divided into three 
phases: pre intervention, interventions (health education of healthy food) and post intervention. ${ }^{[14]}$ Pre intervention consisted of giving informed consent forms to the subjects of this study and their parents and also explaining the way to fill and answer the questionnaire about knowledge and attitudes (see Figure 4). The intervention (implementation of health education) used a flipchart and booklet with a total time of 100 minutes in the classroom, where the children are invited to play with puzzles to match pictures and writing about food items. ${ }^{[15]}$ After a week the implementation of health education in the classroom was then performed by preparing breakfast cooking competitions simultaneously for twenty primary schools with 36 groups. Implementation of competition included selection of the best champion with an established assessment that has been set and judged by a nutritionist as the jury. Methods of education in this intervention are the methods of active learning, so that children can have fun in the learning process. After one week of intervention we conducted a posttest ${ }^{[16]}$

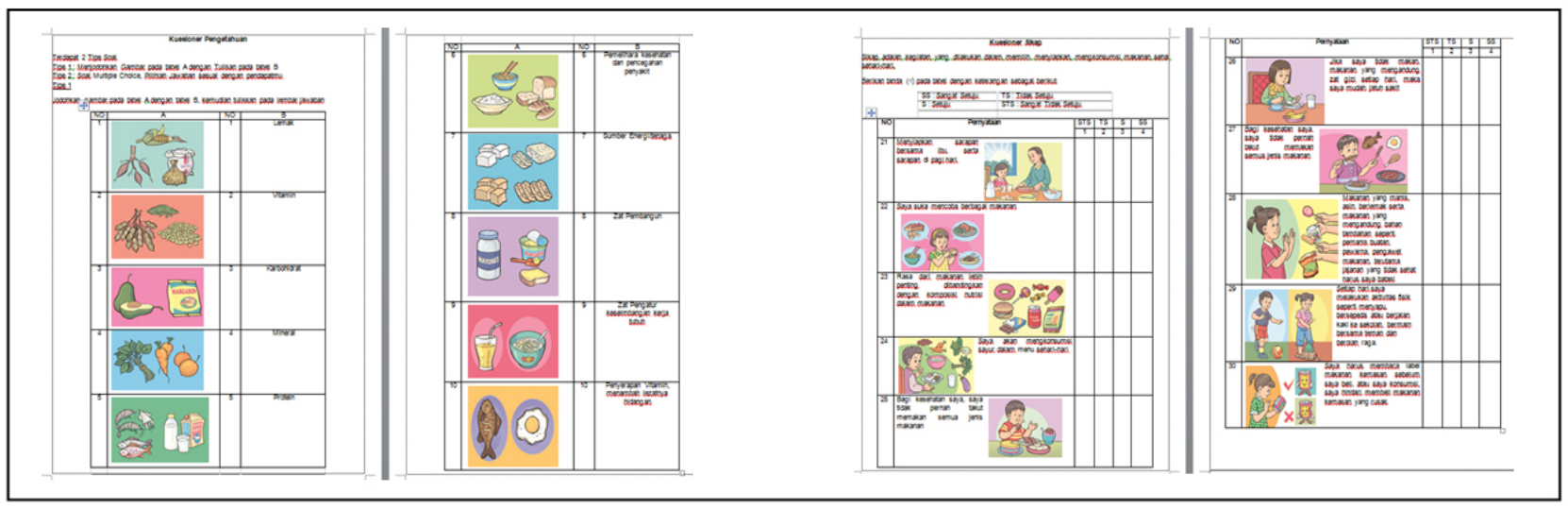

Figure 4. Representation of Questionnaire Knowledge and Attitude

\subsection{Data analyses}

Data were analyzed with statistical calculations using SPSS version 21. Univariate data tests were used to determine the frequency distribution of the personal data of respondents that included: gender and ages of children, parental education, and parental occupation. Normality test for the distribution of data used the Kolmogorov Smirnov test. To determine the ratio before and after the intervention, the Paired-sample $t$-test was used for normally distributed data. However, in this study, the data were not normally distributed and therefore we used the Wilcoxon test.

\section{Results}

\subsection{Characterization of school age children from this study}

Cangkringan is one of the districts in Sleman, Yogyakarta, Indonesia. The distance to the Capital District Government Center Sleman is $25 \mathrm{~km}$. and the subdistrict Cangringan has school age children, who are in 20 elementary schools. Health education activities for primary school age children in the district Cangkringan have never been done. Programs from Cangkringan health center for primary school children are screening of health (nutrition, dental health, and vision conditions) through the activities of BIAS (School Children Immunization Month) conducted only on a new student in class I. The Elementary School School Health Unit (UKS) for 20 primary schools does not function continuously; UKS is used only when there is a sick student. From the observations conducted by researchers during the study in the district of Cangkringan, researchers found many hawkers selling unhealthy snacks like Cimol, cilok, ice, meatball skewers, and assorted toys in front of the school, resulting in nearly 20 primary schools where there are sellers at the gate of the school. This pattern is one reason why the researchers think the school children continue to prefer to eat unhealthy foods. The first intervention was Health education with media flipchart and booklet with a time of 100 minutes in the classroom, where the children are invited to play with puzzles to match pictures and writing about food items and healthy ingredients.

Table 1 provides analysis of data correlation between the work of the father, mother occupation, the influence of others, the influence of media information on the level of knowledge of children and the results showed no correlation between knowledge and attitudes of healthy food.

\subsection{Knowledge and attitudes of healthy food}

Table 2 described the respondents' answers to the questionnaires pretest and posttest about health education. The ques- 
tionnaires have four indicators, namely food nutrients, function of nutrients, objectives of physical activities and examples of physical activities. Difference between the tests' results before and after the Health education was given was $10.47 \pm 2.9 \%$ increased to $12.35 \pm 2.6 \%$ showing a significant difference $(p<.0001)$.

Table 3 described the results of the answers about the respondents' attitudes. There are five indicators that were asked about: 1) The necessity to eat a variety of foods; 2) The importance of the composition of the food; 3) Sufficient supply of water; 4) The importance of food intake for growth and development factors; and 5) Consumption of side dishes of high protein, and restriction of sugary-salty-fatty foods. Results of the effect of health education on children's attitudes about healthy foods show that there are differences in median percent measuring attitudes about healthy eating among school-age children before and after health education, where before health education 27.98 with a mean changing to 29.04 with $(p<.001)$ after, the health education.

Table 2. Table of knowledge questionnaire answer before and after health education $(\mathrm{n}=338)$

\begin{tabular}{|c|c|c|c|c|c|c|c|c|c|c|c|c|}
\hline \multirow{3}{*}{ Indicators } & \multicolumn{4}{|c|}{ Answer of Pre-Test Results } & \multicolumn{4}{|c|}{ Answer of Post-Test Results } & \multirow{3}{*}{$\begin{array}{l}\text { Before } \\
\text { (Mean } \pm \\
\text { SD) }\end{array}$} & \multirow{3}{*}{$\begin{array}{l}\text { After } \\
\text { (Mean } \pm \\
\text { SD) }\end{array}$} & \multirow{3}{*}{$t$} & \multirow{3}{*}{$p$} \\
\hline & \multicolumn{2}{|l|}{ True } & \multicolumn{2}{|l|}{ False } & \multicolumn{2}{|l|}{ True } & \multicolumn{2}{|l|}{ False } & & & & \\
\hline & $\mathbf{n}$ & $\%$ & $\mathbf{n}$ & $\%$ & n & $\%$ & $\mathbf{n}$ & $\%$ & & & & \\
\hline Function of nutrients & 79.4 & 23.4 & 258.6 & 76.5 & 100.4 & 29.7 & 237.4 & 70.2 & & & & \\
\hline The food be restricted & 293 & 86.7 & 45 & 13.3 & 307 & 90.8 & 31 & 9.2 & & & & \\
\hline Drinks be restricted & 236 & 69.8 & 102 & 30.2 & 262 & 77.5 & 76 & 22.5 & & & & \\
\hline Grateful for food & 298 & 88.2 & 40 & 11.8 & 317 & 93.8 & 21 & 6.2 & & & & \\
\hline An additional material for food & 270 & 79.9 & 68 & 20.1 & 296 & 87.6 & 42 & 12.4 & & & & \\
\hline Objective of breakfast & 272 & 80.5 & 66 & 19.5 & 310 & 91.7 & 28 & 8.3 & & & & \\
\hline Sufficient water & 154 & 45.6 & 184 & 54.4 & 251 & 74.3 & 87 & 25.7 & & & & \\
\hline Importance of label & 241 & 71.3 & 97 & 28.7 & 270 & 79.9 & 68 & 20.1 & & & & \\
\hline Wash hands Function & 220 & 65.1 & 118 & 34.9 & 258 & 76.3 & 80 & 23.7 & & & & \\
\hline Objective of physical activity & 128 & 37.9 & 210 & 62.1 & 183 & 54.1 & 155 & 45.9 & & & & \\
\hline
\end{tabular}

Table 3. Frequency distribution of the questionnaire answers students' attitudes about healthy foods before and after intervention $(\mathrm{n}=338)$

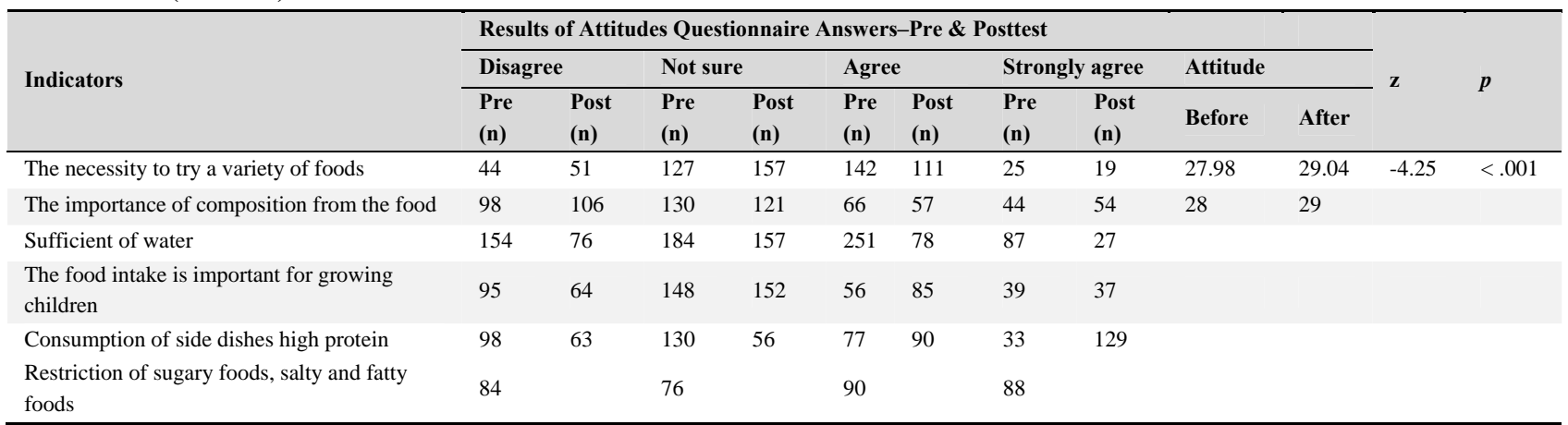

The second intervention of this study involved conducting a cooking competition between groups. Respondents were invited to prepare a breakfast menu of fried vegetable and rice dishes and sandwiches. Researchers provided a cash prize of compensation of IDR 20,000 ( $\sim 2 \$$ USD) for the one winning group. Cooking stuffs and equipment were prepared by the participants. This cooking competition was attended by all 36 groups of 20 elementary schools at Cangkringan district who participated in this study. The cooking competition was done in the pavilion area of the village hall at Argomulyo. Students looked very enthusiastic about cooking, producing a variety of processed menu items, which were enjoyed by all as expressed by the participants and their parents and school teachers. At the time of the assessment process students were invited to present the results of their cooking to the jury including detailed expenses for the food, types of processing and sorts of the content of nutrients contained in the food that had been cooked.

\section{Discussion}

There are various ways of promoting health education for school-age children that were implemented in this study. Our 
study demonstrated that active learning through 'learning with fun approach' using a cooking class and booklet as learning media and small working groups, may increase participation of learning the importance of healthier meals for elementary school students and thus make learning become more real and meaningful for them. This educational method is previously proved to increase the knowledge and attitudes of children about healthy food intake. ${ }^{[8]}$

Flipcharts are a practical media for providing educational material, which can be done simply and does not need complicated strategies, nor any electricity when using it. ${ }^{[17]}$ The advantages here are booklets can be stored longer, can be read back during leisure time, and the reader also can adjust and learn independently. ${ }^{[18]}$ The booklet is also a media for nurses to provide information about healthy food for their patients who are the school age children. ${ }^{[19]}$

Activities outside the classroom served to promote the psychomotor ability of the children, helping them to be able independently to prepare a healthy breakfast. ${ }^{[20]}$ Breakfast is a very important meal for everybody to start the day with adequate nutrition and therefore children who eat a complete breakfast compared to a partial one, make fewer mistakes and work faster in math and number checking tests. ${ }^{[21]}$ Children who eat breakfast also show improved cognitive function, attention, and memory. ${ }^{[22]}$

School-age children in this mountainous Indonesian area after the volcanic disaster have been accustomed to eat food instant food, so there have been daily consumption patterns that are not healthy. This pattern is reflected in the behavior of children with the consumption of instant noodles, canned fish consumption as a side dish, and eating unhealthy snack food while in school. In this study, knowledge and attitudes have increased significantly, before and after intervention through a fun approach to healthy food. Through the learning process the participants can better understand that the

\section{REFERENCES}

[1] Del Rosso JM, Marek T. Investing in School Health and Nutrition in Indonesia. Basic Education Capacity Trust Fund, 2009.

[2] Bandura A. A social cognitive theory of personality. In L. Pervin \& O. John (Ed.), Handbook of personality (2nd ed., pp. 154-196). New York: Guilford Publications. (Reprinted in D. Cervone \& Y. Shoda [Eds.], The coherence of personality. New York: Guilford Press; 1999.

[3] Leong CS, Lynn B. Active learning improves nursing student clinical performance in an academic institution in Macao. Chinese Nursing Research Journal. 2015; 2: 35-39. http://dx.doi .org/10. 1016

Published by Sciedu Press homemade food is better, and healthier than any food from the foodstalls. ${ }^{[16]}$

Community nurses are expected to provide education for school age children including how to prepare and consume healthy food. As nurses and medical educators, we recommended that the healthy food intake should be embedded in the basic curriculum of elementary school, and become a part of the 'living skills' subject. The results of this study provide feedback that primary school children should be able to recognize and prepare food for daily consumption, thus further providing a model that can improve health status of all children. ${ }^{[23]}$

\section{Conclusions}

Health education for school aged children with active learning methods using a booklet, flip chart and cooking competition was useful to supplement knowledge and positive attitudes of the students to select a more healthy daily food intake.

\section{IMPLICATION FOR NURSING EDUCATION}

There are essential roles for nurses who serve the community to provide more attention to promote health food intake for school age children. An engaging 'learning with fun' approach is needed to introduce healthy food intake for school age children. Creativity of nurses to design learning experiences, which involve school age children to actively participate in the learning courses, should be encouraged.

\section{ACKNOWLEDgements}

We would like to thank all school-age children who have been willing to participate in this study, and thanks to educators and all research assistants to assist throughout this study.

\section{CONFlicts OF INTEREST Disclosure}

The authors declare that there is no conflict of interest. /j.cnre.2015.08.001

[4] Scotish Education. How Good Our School?. HM Inspectorate of Education, Denholm House, Almondvale Business Park, Almondvale Way, Livingston. 2015. Available from: https://www . educatio nscotland.gov.uk/Howgoo

[5] Lin W. Nutrition knowledge, attitude, and behavior of Taiwanese elementary school children. Asia Pac J Nutrition. 2007; 16 (S2): 534-546.

[6] Marcia R. Obesity, eating habbits and nutritional knowledge among school children. Rev Saude Publica. 2005; 39(4).

[7] Utter J, Lucassen M, Ben D. Adolescent cooking abilities and behav- 
iors: Associations with nutrition and emotional well-being. Journal of Nutrition Education and Behavior. 2016; 48(1).

[8] Sebold LB. Active methodologies as strategies in nursing teaching: Raising awareness towards healthy habits. Journal of Nursing Education and Practice. 2013; 3(6): 43-50. http://dx . doi .org/10.54 $30 /$ jnep. v3n6p43

[9] Departement for Health Research and Development. Basic Health Research. Jakarta: The Ministry of Health of the Republic of Indonesia. 2013.

[10] Michael H. Nursing's role in Nutrition. 2009.

[11] The Ministry of Health of the Republic of Indonesia. Nutrition food emergency care civil defense disaster. Jakarta: The Ministry of Health of the Republic of Indonesia. 2012.

[12] Harry N, Boone J. Analyzing Likert Data. Journal of Extension Volume 50 Number 2 Article Number 2TOT2. 2012.

[13] Zalilah MS, Norlijah O. Nutrition Education Intervention Improves Nutrition Knowledge, Attitude and Practices of Primary School Children: A Pilot Study. International Electronic Journal of Health Education. 2008; 11: 119-132.

[14] I-Tech (International Training and Education Center for Health). Guidelines for Pre and Post Testing. University of Washington. 2008.

[15] Wijayanti. Promoting healthy food education for elementary school children at post Merapi eruption area of Cangkringan district Yogyakarta Indonesia: a quasi experiment study using learning with fun approach. A Master Thesis. Submitted to the Departement of Nursing Gadjah Mada University. 2015.

[16] Thompson J, Manore M. Nutritional an Applied Approach. Second Edition. Pearson Benjamin Cummings. 2010; 528-569,651.
[17] Caniza EJ, Moore Y, Liu Q. Effective hand hygiene education with the use of flipcharts in a hospital in El Salvador. Journal of Hospital Infection. 2007; 65: 58-64. PMid:17147972 http://dx.doi.org /10.1016/j.jhin.2006.08.011

[18] Christine N, Ailsa H, Julie D, et al. Faecal incontinence intervention study (FINS): self-management booklet information with or without nurse support to improve continence in people with inflammatory bowel disease: study protocol for a randomized controlled trial. BioMed Central. 2015; 16: 444.

[19] Sheyla C, Ana F. Development and validation of an educational booklet for healthy eating during pregnancy. Revista Latino-Americana de Enfermagem July-Aug. 2014; 22(4): 611-20. http://dx.doi .o rg/10.1590/0104-1169.3313.2459

[20] Marla R, Trofholz AC, Laska MN. Impact of cooking and home food preparation interventions among adults: Outcomes and implications for future programs. Journal of Nutrition Education and Behavior. 2014; 46(4).

[21] Wyon D, Abrahamsson L, Jartelius M, et al. An experimental study of the effects of energy intake at breakfast on the test performance of 10 year-old children in school. International Journal of Food Science and Nutrition. 1997; 48(1): 5-12. http://dx.doi.org/10.3109 /09637489709006958

[22] Wesnes KA, Pincock C, Richardson D, et al. Breakfast reduces declines in attention and memory over the morning in schoolchildren. Appetite. 2003; 41(3): 329-31. http://dx.doi.org/10.1016/j . appet. 2003.08 .009

[23] Leslie CSP, Barbara L. Impact of a School-Based Cooking Curriculum for Fourth-Grade Students on Attitudes and Behaviors Is Influenced by Gender and Prior Cooking Experience. Journal of Nutrition Education and Behavior. 2014; 46(2). 